\title{
The main phosphorous sources in the Changjiang estuary*
}

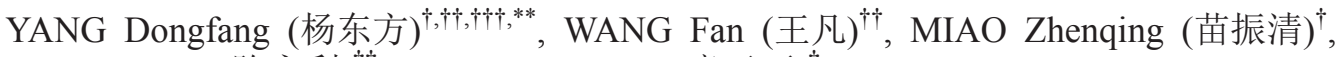 \\ CHEN Yongli (陈永利) ${ }^{\dagger \dagger}$, TONG Yuanzheng (童元正) ${ }^{\dagger}$ \\ ${ }^{\dagger}$ Marine Science College, Zhejiang Ocean University, Zhoushan 316000, China \\ ${ }^{+1}$ Institute of Oceanology, Chinese Academy of Sciences, 7 Nanhai Road, Qingdao 266071, China \\ ttt State Key Laboratory of Urban and Regional Ecology, Research Center for Eco-Environmental Science, Beijing 100085 , \\ China
}

Received July 23, 2007; revision accepted Aug. 7, 2008

\begin{abstract}
Analysis using historical data on the phosphate sources in Changiiang (Yangtze River) estuary show that phosphate was supplied equally from the east, south, west and north of the estuary. These sources include the Changiiang River, the Taiwan Warm Current (TWC), a cyclone-type eddy, and the $32^{\circ} \mathrm{N}$ Upwelling, supplying different phosphates in different times, ways and intensities. The magnitude of their supplying phosphate concentration was related with the size in the order of the Changjiang River $<$ the TWC $<$ the $32^{\circ} \mathrm{N}$ Upwelling $<$ the cyclone-type eddy, and the duration of the supplying was: the Changjiang River $>$ the TWC $>$ the cyclone-type eddy $>$ the $32^{\circ} \mathrm{N}$ Upwelling. The four sources supplied a great deal of phosphate so that the phosphate concentration in the estuary was kept above $0.2 \mu \mathrm{mol} / \mathrm{L}$ in previous years, satisfying the phytoplankton growth. The horizontal and vertical distribution of the phosphate concentration showed that near shallow marine areas at $122^{\circ} \mathrm{E} / 31^{\circ} \mathrm{N}$, the TWC in low nutrient concentration became an upwelling through sea bottom and brought up nutrients from sea bottom to marine surface. In addition, horizontal distribution of phosphate concentration was consistent with that of algae: Rhizosolenia robusta, Rhizosolenia calcaravis and Skeletonema, which showed that no matter during high water or low water of Changjiang River, these species brought by the TWC became predominant species. Therefore, the authors believe that the TWC flowed from south to north along the coast and played a role in deflecting the Changjiang River flow from the southern side.
\end{abstract}

Keyword: Changjiang estuary; phosphate sources; Taiwan Warm Current; the $32^{\circ} \mathrm{N}$ Upwelling; cyclone-type eddy;

\section{INTRDUCTION}

In the south of the Changjiang estuary, the Taiwan Warm Current (TWC) flowed northward; its sharp front arrives at the seawaters in the north of $30^{\circ} \mathrm{N}$ across the estuary. In the north of the estuary, Subei (Northern Jiangsu) Coastal Current and Yellow Sea Coastal Current flowed southward. The northward TWC, southward Subei coastal current and Yellow Sea coastal current with fresh water of Changjiang River met and mixed in the estuary, having an important effect on the distribution and variation of hydrological factors in the area.

From August 1985 to August 1986, a hydrological investigation was carried out in Changjiang estuary, covering maritime zones of the Yellow Sea and East China Sea in the west of $124^{\circ} \mathrm{E}$ between $30^{\circ} 45^{\prime}-32^{\circ} \mathrm{N}$. Caused by huge amount of fresh water from Changjiang River into the sea, the temperature rises at the marine surface, and the water body forms a strong fresh water tongue with distinct borders. The water body does not move southeast-ward, the same as the direction of the mouth of Changjiang River into the sea, but often turned northeast-ward. The larger the water flow, the greater the turning degree (Zhao et al., 1992).

The TWC is ocean water mass with high salinity and low turbidity, having very warm surface water and high salinity, and originated from the Taiwan

\footnotetext{
*Supported by Key Laboratory of Marine Spill Oil Identification and Damage Assessment Technology, SOA, the Director's Foundation of the North Sea Monitoring Center, and Chinese Academy of Sciences (No. KZCX 2-207), and the Project of Ecological Environment in Fishery and Technology Controlling Pollution in Zhoushan Fishing Ground (No. 2007c23075)

** Corresponding author: dfyang@shfu.edu.cn
} 
Strait and Kuroshio surface, while the water with high salinity in deep layer is originated from the Kuroshio's second surface from the northeast of Taiwan into the continental shelf (Weng and Wang, 1984). The warm and salty TWC formed obvious sharp edge against the two sides of cooler coastal flow of the East China Sea, especially in winter. Pushed by the northeastern seasonal wind, the flow axis of the TWC is close to the marine coast and countermoves southward with the coastal flow. Therefore, meeting the sharp edge is inevitable.

The Changjiang estuary is located at the interface between the Yellow Sea and East China Sea. In the south of this interface, the TWC and its sharp edge went northward over the Changjiang estuary to the north of $32^{\circ} \mathrm{N}$ (Zhao, 1982; Su, 1986); in the north of this interface, Subei coastal current and Yellow Sea coastal current went southward, whose adjacent area was a wide marine area mixed by the Yellow Sea and East China Sea (Su et al., 1983). The mixing water in the front of the TWC going northward arrived at the marine waters of the Changiiang north coast (surpassing $32^{\circ} \mathrm{N}$ ) across the Changjiang fresh water through the bottom layer. As the depth becomes shallower, the water of low oxygen in bottom layer could affect the surface layer (Su, 1986).

In spring, April 1994, the waters with low temperature and high salinity existed in the transition of $31^{\circ} \mathrm{N}$. In the whole water layer in $123.5^{\circ}-124.5^{\circ} \mathrm{E}$, the salinity in the core could reach $34.2^{\circ} \mathrm{N}$. The second surface water in deep of the TWC could also reach $31^{\circ} \mathrm{N}$ in spring, and tend to expand to $32^{\circ} \mathrm{N}$, and then rose to the marine surface in the north of $31^{\circ} \mathrm{N}$ (Wang et al., 2001).

The cyclone-type eddy was a second-level small counterclockwise current in the Yellow Sea and East China Sea, and closely related with the sea bottom landform in the studied area: $30^{\circ} 30^{\prime}-30^{\circ} 00^{\prime} \mathrm{N}$, $124^{\circ} 00^{\prime}-127^{\circ} 00^{\prime} \mathrm{E}$, and the lateral shear effect of the two marine currents in reversal directions between the warm current and coastal current of the Yellow Sea $(\mathrm{Hu}, 1984)$. With the in situ data of normal temperature, salinity and flow, the analysis proved that in summer 1972 there was a weak cyclone-type eddy, small at upside, and large at downside, in average size of more than 90 nautical mile. The cyclone-type eddy gryed up and resulted in deep cold water rising at vertical average flow speed of about $4.3 \mathrm{~cm} / \mathrm{s}$ by calculation. It is considered that the existence and development of the deep water of low temperature in summer, the bottom landform, and the lateral shear of the two marine currents in reversal directions decided the formation and the shape of the cyclone-type eddy; wind field and typhoon in summer had no direct relationship with it. In the studied area, the sediment showed an isolated ooze area that was closely related with the cyclone-type eddy (Hu, 1984).

Under the effect of coastal flow on the coastal side, the content of oxygen and nutrients near the Changjiang estuary was obviously higher than that in the open sea. Subei coastal current flowed near the Changjiang estuary, a part of which went over shallow Changjiang estuary into Jiangsu-Zhejiang coastal flow to the south, and the other parts, being blocked by the northwestward TWC, turned to the east and merged to the southeast into the water system of the Yellow Sea. Moreover, these characteristics above were apparently approved by the distribution of the temperature and salinity (Jiang and Wang, 1990).

The investigation data from August 1985 to August 1986 in Changjiang estuary show that in some transects from the estuary to open sea, the phosphate concentration was not always lower with the distance away from the coast-line and had no seasonal variation in cycle. In some transects, the phosphate concentration did not fall, but rose or stayed (Yang et al., 2005; 2006). Thereby, for the estuary, the authors wondered the phosphate could be supplied by other sources in addition to the Changjiang, which was just paid attention. This comprehensive analysis on the characteristics of water system in the Changiiang estuary has shown that ample nutrients were supplied from Changiiang River, the TWC, the cyclone-type eddy, and the $32^{\circ} \mathrm{N}$ Upwelling to the east, south, west and north of the Changjiang estuary, respectively, in different time, way, and intensity (Yang et al., 2007).

\section{MATERIALS AND METHODS}

The dataset used in this paper was provided by Institute of Oceanology, Chinese Academy of Sciences, from an investigation carried out August 1985 to February 1986 in 12 cruises (except February). The investigation areas included $120^{\circ} 14^{\prime}-121^{\circ} 54^{\prime} \mathrm{E}$ inside the Changjiang River with eight stations; $122^{\circ}-124^{\circ} \mathrm{E}, 30^{\circ} 45^{\prime}-32^{\circ} 00^{\prime} \mathrm{N}$ in the Changjiang estuary during August, October, May; $122^{\circ}-123^{\circ} \mathrm{E}, \quad 30^{\circ} 45^{\prime}-32^{\circ} 00^{\prime} \mathrm{N}$ during January; $122^{\circ}-123^{\circ} 30^{\prime} \mathrm{E}, 30^{\circ} 45^{\prime}-32^{\circ} 00^{\prime} \mathrm{N}$ during the rest 7 months (Fig.1).

The Raw data included $\mathrm{NO}_{3}^{-}-\mathrm{N}, \mathrm{NO}_{2}^{-}-\mathrm{N}, \mathrm{NH}_{4}^{+}-\mathrm{N}$, 
$\mathrm{SO}_{3-}^{2-} \mathrm{Si}, \mathrm{PO}_{4}^{3-}-\mathrm{P}$. Nutrients were determined by a Technicon II Auto Analyzer. Water samples of the nutrients were collected with stainless steel water sampler (at surface, $5 \mathrm{~m}, 10 \mathrm{~m}, 15 \mathrm{~m}$, and near bottom), stored in polyethylene bottles, and deep frozen below $-25^{\circ} \mathrm{C}$ in a refrigerator. Clear liquid in the upper layer was measured after thawing in laboratory.

\section{RESULTS}

\subsection{August 1985}

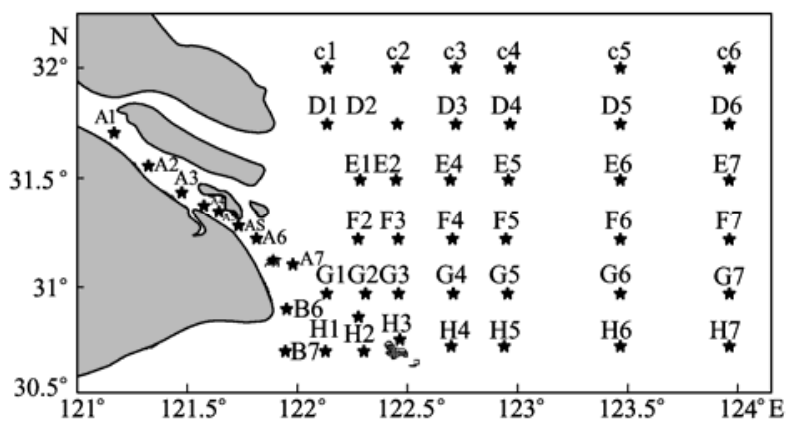

Fig.1 Sampling sites in Changjiang estuary, China

The horizontal distribution (Fig.2) revealed a water mass between $121.5^{\circ}-122.75^{\circ} \mathrm{E}$ and $30^{\circ}-31.75^{\circ} \mathrm{N}$, with more than $0.8 \mu \mathrm{mol} / \mathrm{L}$ of phosphate concentration. Two areas, one in $121.75^{\circ} \mathrm{E} / 31.25^{\circ} \mathrm{N}$, the phosphate concentration reached $0.9 \mu \mathrm{mol} / \mathrm{L}$, and another in $123.5^{\circ}-124^{\circ} \mathrm{E} / 30.75^{\circ} \mathrm{N}$, the concentration was 0.8 $\mu \mathrm{mol} / \mathrm{L}$. The concentration gradually decreased northeastward, indicating that the high phosphate concentration was sourced from the south.

The area at $121.75^{\circ} \mathrm{E} / 31.25^{\circ} \mathrm{N}$ was just located in the strong mixing zone between the river fresh water and seawater. Between the coastal line and $122.25^{\circ} \mathrm{E} / 30.5^{\circ} \mathrm{N}$, the flow with more than $0.8 \mu \mathrm{mol} / \mathrm{L}$ of phosphate concentration ran northeastward along the coast, centered at $122.25^{\circ} \mathrm{E} / 31.1^{\circ} \mathrm{N}$.

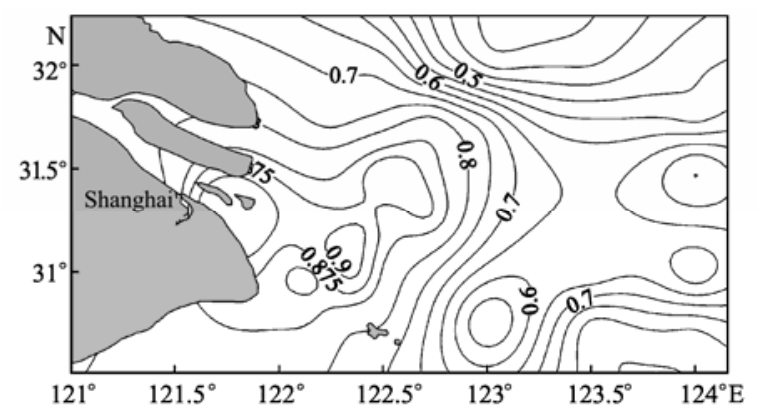

Fig.2 The horizontal distribution of phosphate concentration $(\mu \mathrm{g} / \mathrm{L})$ in August 1985

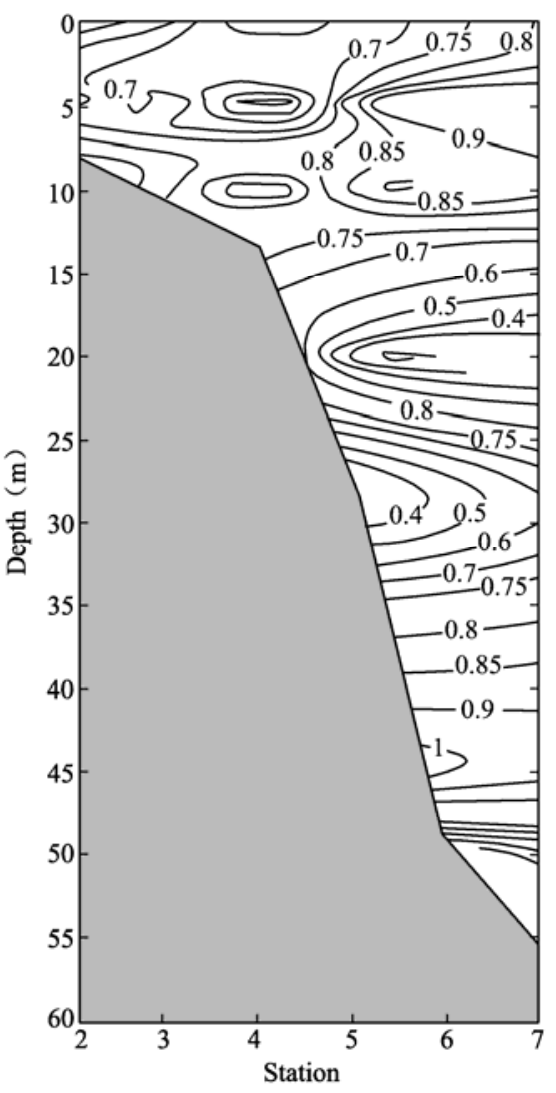

Fig.3 The distribution of phosphate concentration $(\mu \mathrm{g} / \mathrm{L})$ in August 1985 at transect $H$

The transect $\mathrm{H}$ (Fig.3) shows that the marine current rushed at the slope, took up nutrient phosphorus, and then left the slope and rose obliquely.

The transect F (Fig.4) shows that same to the transect $\mathrm{H}$, the current took up nutrient phosphorus from sea bottom to the surface. At the transect $\mathrm{H}$ and $F$, the nutrient phosphorus concentration was low.

\subsection{September 1985}

The horizontal distribution (Fig.5) in $121.8^{\circ}-122.4^{\circ} \mathrm{E} / 30.4-31^{\circ} \mathrm{N}$ shows that the phosphate concentration was $>0.8 \mu \mathrm{mol} / \mathrm{L}$, and $1.1 \mu \mathrm{mol} / \mathrm{L}$ in the center at $122.1^{\circ} \mathrm{E} / 30.8^{\circ} \mathrm{N}$, which shows, the current with the phosphate concentration $0.8 \mu \mathrm{mol} / \mathrm{L}$ flowed southwest to northeast. At $122.5^{\circ} \mathrm{E} / 32^{\circ} \mathrm{N}$, the concentration in the waters reached $1.5 \mu \mathrm{mol} / \mathrm{L}$, and along the coast in the west of the waters or in the open sea in the east of the waters, phosphate concentration was very low, which indicates that the high phosphate concentration in the waters was resulted from the upwelling from the sea bottom to the sea surface. 


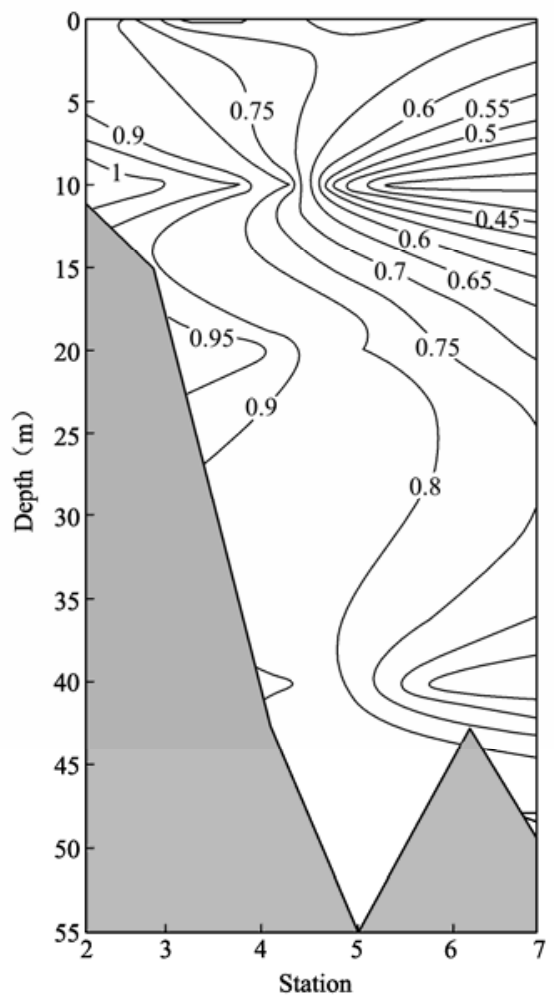

Fig.4 The distribution of phosphate concentration $(\mu \mathrm{g} / \mathrm{L})$ in August 1985 at transect F

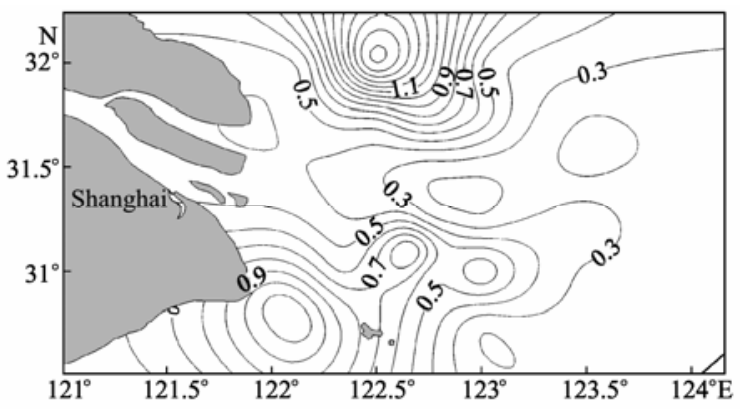

Fig.5 The horizontal distribution of phosphate concentration $(\mu \mathrm{g} / \mathrm{L})$ in September 1985

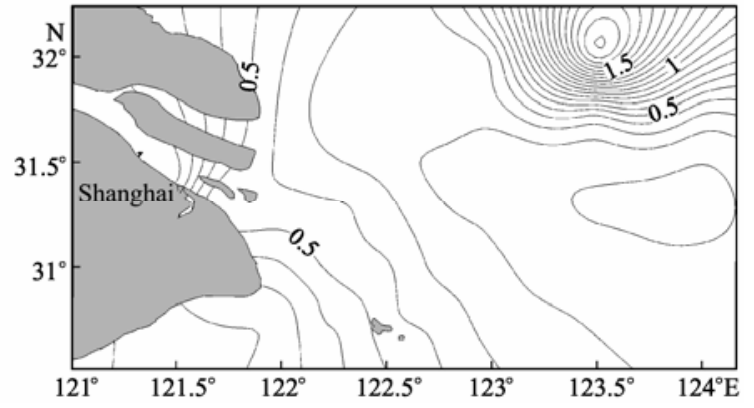

Fig.6 The horizontal distribution of phosphate concentration $(\mu \mathrm{g} / \mathrm{L})$ in October 1985

\subsection{October 1985}

In the waters $123.2-124^{\circ} \mathrm{E} / 31.8-32.5^{\circ} \mathrm{N}$, the phosphate concentration reached $>0.8 \mu \mathrm{mol} / \mathrm{L}$. The

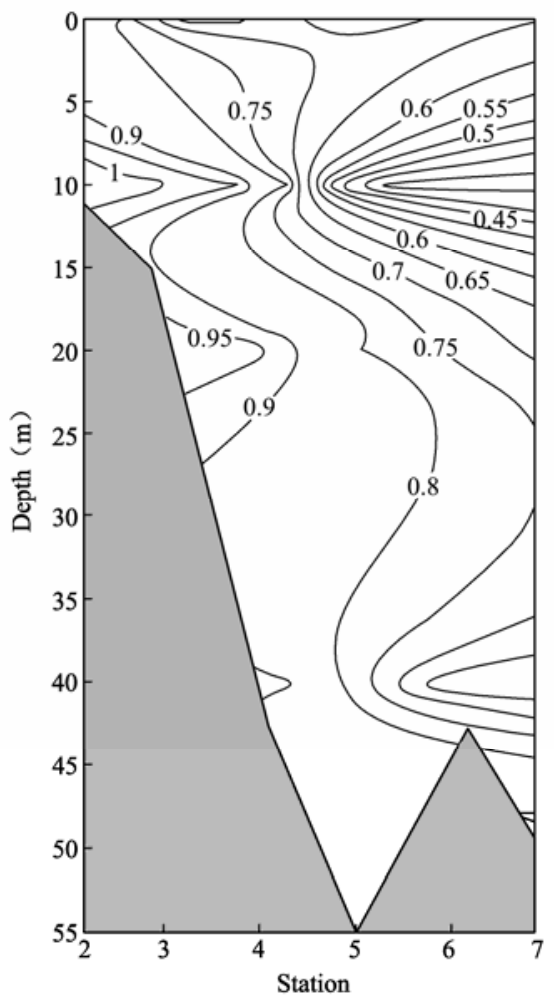

Fig.7 The distribution of phosphate concentration $(\mu \mathrm{g} / \mathrm{L})$ in October 1985 at transect $\mathbf{C}$

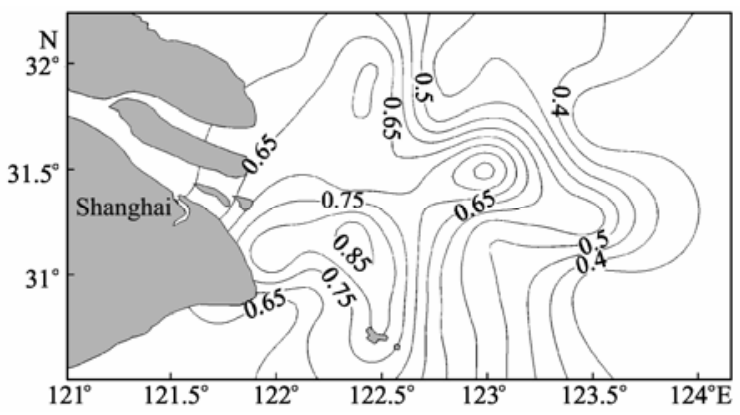

Fig.8 The horizontal distribution of phosphate concentration $(\mu \mathrm{g} / \mathrm{L})$ in November 1985

area centered at $123.5^{\circ} \mathrm{E} / 32.1^{\circ} \mathrm{N}$, the phosphate concentration was over $1.7 \mu \mathrm{mol} / \mathrm{L}$ (Fig.6), was away from the estuary, where no land source should have been available, but upwelling, whereas in the estuary and nearby waters phosphate concentrations were almost even at about $0.5 \mu \mathrm{mol} / \mathrm{L}$.

The profile of transect $\mathrm{C}$ (Fig.7) shows that the water mass of high phosphate concentration was not provided by any vertical current and the current from the west.

\subsection{November 1985}

In the waters $122^{\circ}-122.5^{\circ} \mathrm{E} / 30.8^{\circ}-31.2^{\circ} \mathrm{N}$, the phosphate concentration reached $>0.8 \mu \mathrm{mol} / \mathrm{L}$ (Fig.8). In the southern coastal waters of the Changjiang 


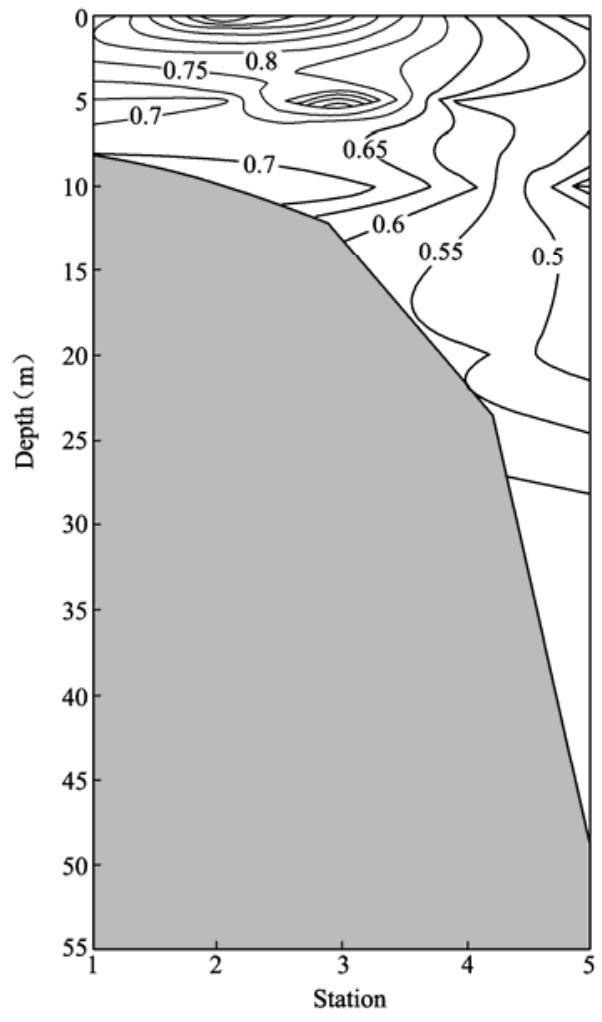

Fig.9 The distribution of phosphate concentration $(\mu \mathrm{g} / \mathrm{L})$ in November 1985 at transect $\mathbf{G}$

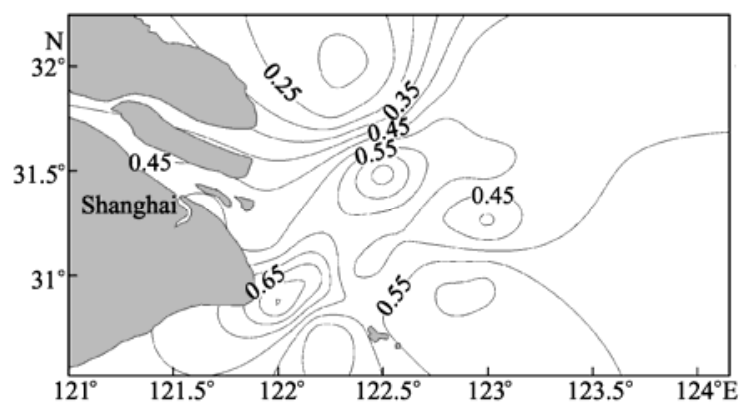

Fig.10 The horizontal distribution of phosphate concentration $(\mu \mathrm{g} / \mathrm{L})$ in December 1985

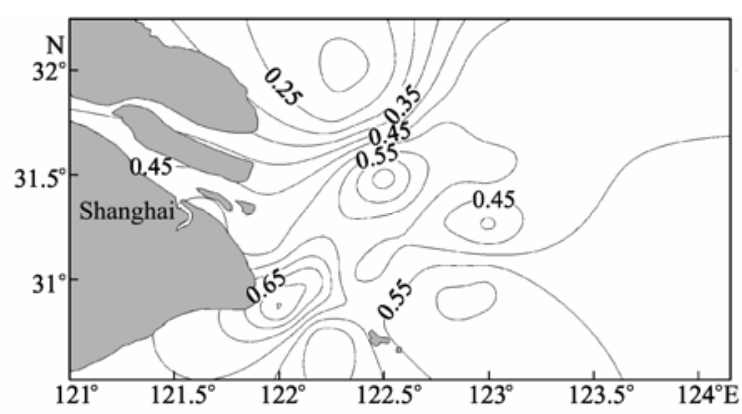

Fig.11 The horizontal distribution of phosphate concentration $(\mu \mathrm{g} / \mathrm{L})$ in January 1986

estuary, a tongue shaped water mass appeared from the southwest to the northeast along the coastline and beyond, where phosphate concentration increased from $0.65 \mu \mathrm{mol} / \mathrm{L}$ to $0.85 \mu \mathrm{mol} / \mathrm{L}$. In the whole area investigated, the concentration was $>0.4$ $\mu \mathrm{mol} / \mathrm{L}$.

The profile of transect $G$ (Fig.9) shows, the marine current brought up high phosphate concentration water at the sea bottom to the marine surface.

\subsection{December 1985}

In, in the waters $122^{\circ}-122.6^{\circ} \mathrm{E} / 30.8^{\circ}-31^{\circ} \mathrm{N}$, the high phosphate concentration, brought by the water current from the south to the west, reached $>0.8 \mu \mathrm{mol} / \mathrm{L}$ (Fig.10), when the water current flowed along the southern coast of the Changjiang estuary to $31^{\circ} \mathrm{N}$, the concentration fell gradually. However, in any other waters there was not a water mass of high phosphate concentration.

\subsection{January 1986}

In the horizontal distribution of phosphate, phosphate concentration was $>0.25 \mu \mathrm{mol} / \mathrm{L}$, and dropped from south to north from 0.7 to about $0.25 \mu \mathrm{mol} / \mathrm{L}$. In several water masses, the concentration was $<0.7 \mu \mathrm{mol} / \mathrm{L}$, centered at $122.5^{\circ} \mathrm{E} / 31.5^{\circ} \mathrm{N}$, $122^{\circ} \mathrm{E} / 30.9^{\circ} \mathrm{N}$, and $22.8^{\circ} \mathrm{E} / 30.9^{\circ} \mathrm{N}$. However, the phosphate concentration from the Changiang estuary was $<0.45 \mu \mathrm{mol} / \mathrm{L}$.

\subsection{March 1986}

A water mass of high concentration at $1 \mu \mathrm{mol} / \mathrm{L}$ occurred in center of $122^{\circ} \mathrm{E} / 31.1^{\circ} \mathrm{N}$, and $>0.8$ $\mu \mathrm{mol} / \mathrm{L}$ in $121.9^{\circ}-122.2^{\circ} \mathrm{E}$. Isolines of phosphate concentration (Fig.12) show that some water currents in the surface waters of the Changiiang estuary provided the source for high phosphate concentration. However, the Changjiang estuary could provide the phosphate to the concentration below $0.6 \mu \mathrm{mol} / \mathrm{L}$, and the rest should be provided by upwelling. And the phosphate concentration in $32^{\circ} \mathrm{N}$ zone was also very high, because the water current ran from the north to south. In addition, in waters $124^{\circ} \mathrm{E} / 31.5^{\circ} \mathrm{N}$, the east-west water current brought water of higher phosphate concentration $(>0.65 \mu \mathrm{mol} / \mathrm{L})$. Therefore, phosphate source could be provided into the Changjiang estuary from different directions.

\subsection{April 1986}

In the whole waters, there was no water mass of high phosphate concentration, and the concentration was evenly-distributed in $0.3-0.47 \mu \mathrm{mol} / \mathrm{L}$.

\subsection{May 1986}

In the whole waters, phosphate concentration was 


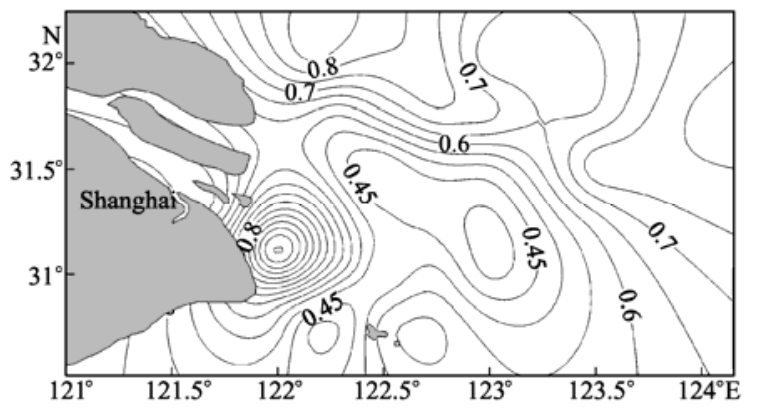

Fig.12 The horizontal distribution of phosphate concentration $(\mu \mathrm{g} / \mathrm{L})$ in March 1986

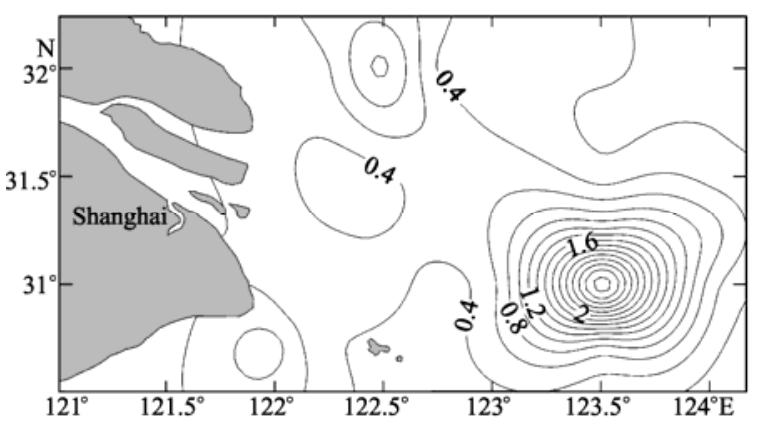

Fig.13 The horizontal distribution of phosphate concentration $(\mu \mathrm{g} / \mathrm{L})$ in May 1986

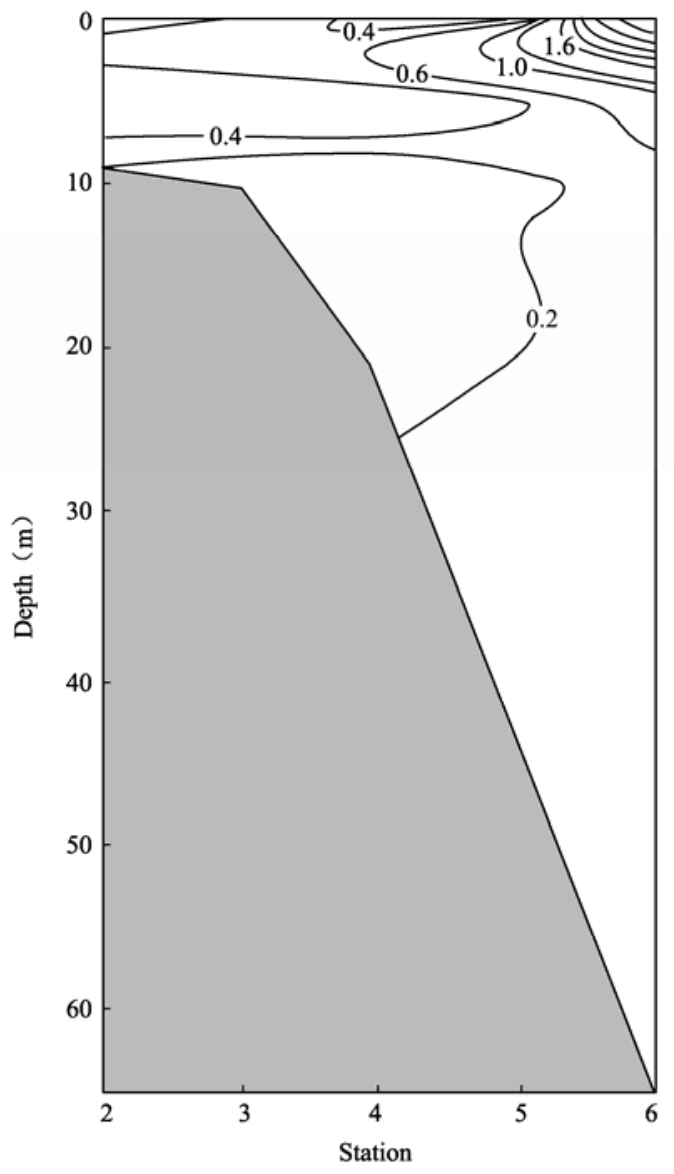

Fig.14 The distribution of phosphate concentration $(\mu \mathrm{g} / \mathrm{L})$ in May 1986 at transect $\mathbf{G}$ at $0.4-0.6 \mu \mathrm{mol} / \mathrm{L}$ (Fig.13). In the water mass $123.2^{\circ}-124^{\circ} \mathrm{E} / 30^{\circ}-31.4^{\circ} \mathrm{N}$, the concentration was $>$ $0.8 \mu \mathrm{mol} / \mathrm{L}$. At the center of the water mass $\left(123.5^{\circ} \mathrm{E} / 31^{\circ} \mathrm{N}\right)$, the concentration was $2.4 \mu \mathrm{mol} / \mathrm{L}$, which was much higher than that in the estuary. The profile of transect $G$ (Fig. 14) shows, at depth 0-10 $\mathrm{m}$, high phosphate concentration water was not transported by river from the west, but by marine bottom current to the surface, except for the area to the east.

The transect $\mathrm{H}$ (Fig.15) shows, the phosphate concentration was lower, which explains that the high phosphate concentration in the transect $\mathrm{G}$ was not brought by marine current from the south to north.

\subsection{June 1986}

In the whole areas, the phosphate concentration was at $0.2-0.6 \mu \mathrm{mol} / \mathrm{L}$ (Fig.16), indicating the lower phosphate concentration in the Changjiang estuary.

In the estuary, high phosphate concentration was caused only by Changjiang River but by upwelling, the TWC, and cyclone-type eddy, and gradually decreased from the west to the east but still above $0.2 \mu \mathrm{mol} / \mathrm{L}$.

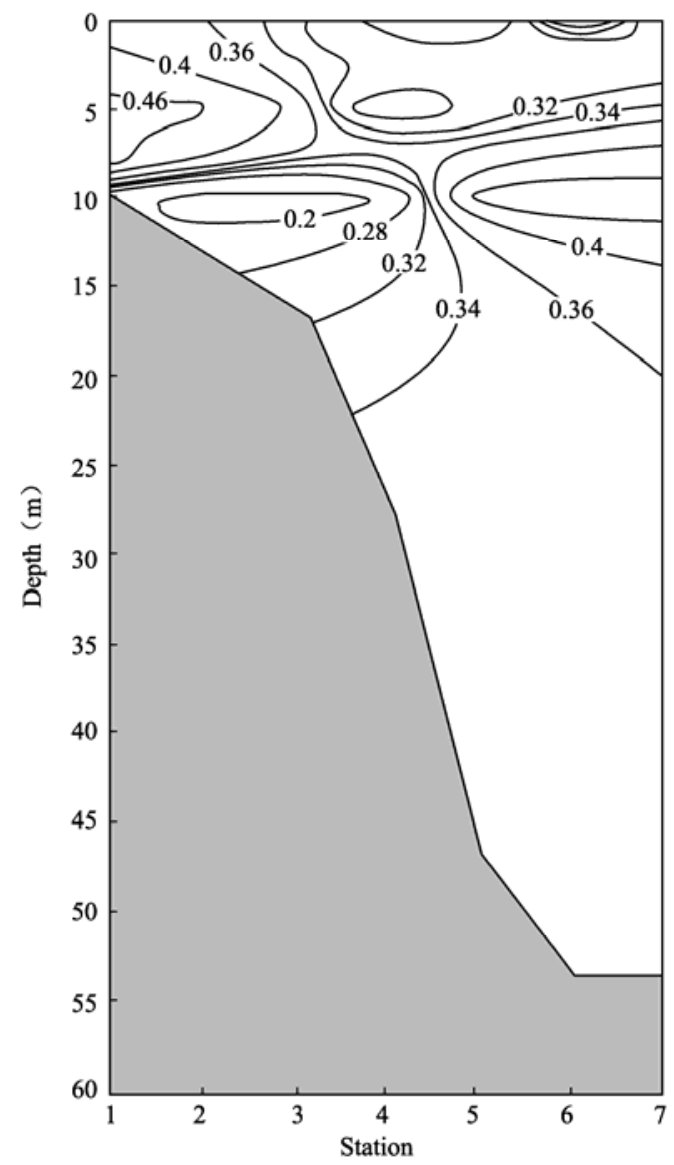

Fig.15 The distribution of phosphate concentration $(\mu \mathrm{g} / \mathrm{L})$ in May 1986 at transect $\mathbf{H}$ 


\subsection{July 1986}

In the most waters, the phosphate concentration was $0.2 \mu \mathrm{mol} / \mathrm{L}$ (Fig.17). Near the estuary from the west to the east, the concentration decreased from 0.7 to $0.2 \mu \mathrm{mol} / \mathrm{L}$ in gradient. In the estuary, there was a weak upwelling with phosphate concentration below $0.7 \mu \mathrm{mol} / \mathrm{L}$.

\subsection{August 1986}

In the whole waters, the phosphate concentration was $>0.2 \mu \mathrm{mol} / \mathrm{L}$ (Fig.18). Near the estuary, the concentration decreased from 0.7 to $0.25 \mu \mathrm{mol} / \mathrm{L}$ in gradient. In the estuary, a weak upwelling was shown with the phosphate concentration of below $0.7 \mu \mathrm{mol} / \mathrm{L}$.

\section{DISCUSSIONS}

\subsection{The Changjiang River for the transportation of nutrient $P$ to the estuary}

The amount of discharge in the Changjiang River was huge, with annually 924 billion $\mathrm{m}^{3}$ fresh water into the sea, of which about $80 \%$ flowed into the Yellow Sea and the East China Sea (Zhao et al., 1992). Seasonal variation in flowage was very remarkable, about $71 \%$ was from May-October (Zhao et al., 1992). Such a huge amount of water could provide constant nutrient phosphorus supply to the estuary. However, for the whole estuary, the magnitude of the Changjiang river flux had no relativity with the phosphate concentration in the sea; the phosphate concentration in the estuary caused by the river was not decided by its high water or low water time (Yang et al., 2005). The phosphate concentration in Changjiang river (Stations: A1, A2, A3, A4, A5) ranged $0.24-1.2 \mu \mathrm{mol} / \mathrm{L}$, commonly $0.3-0.9 \mu \mathrm{mol} / \mathrm{L}$. The Changjiang River-generated phosphate concentration in the estuary was significant being below $0.9 \mu \mathrm{mol} / \mathrm{L}$. In October 1985 , near the estuary at the west of $123^{\circ} \mathrm{E}$, the concentration was about $0.5 \mu \mathrm{mol} / \mathrm{L}$. In January 1986, in the whole estuary, the phosphate was provided by no other sources but the Changiiang River, for the concentration $<0.7 \mu \mathrm{mol} / \mathrm{L}$, mostly $0.25-0.55 \mu \mathrm{mol} / \mathrm{L}$. In May 1986, in the west of $123^{\circ} \mathrm{E}$, the phosphate concentration was about $0.4 \mu \mathrm{mol} / \mathrm{L}$ related to the Changiiang River. In June 1986, in the whole estuary, the phosphate concentration was $0.6-0.2 \mu \mathrm{mol} / \mathrm{L}$ related only to the river, and from western estuary to the east of $124^{\circ} \mathrm{E}$, the phosphate concentration decreased in gradient.

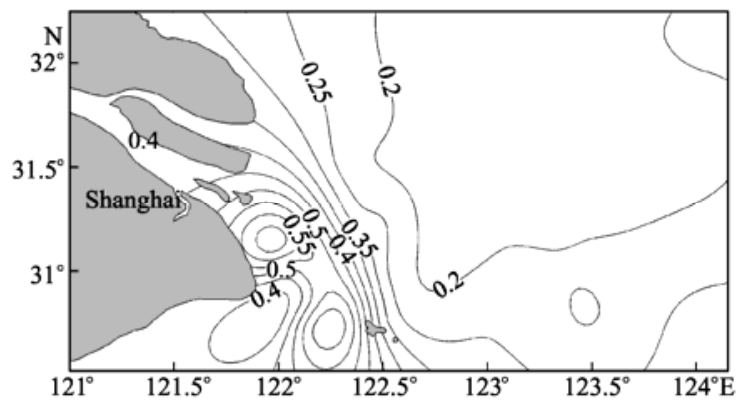

Fig.16 The horizontal distribution of phosphate concentration $(\mu \mathrm{g} / \mathrm{L})$ in June 1986

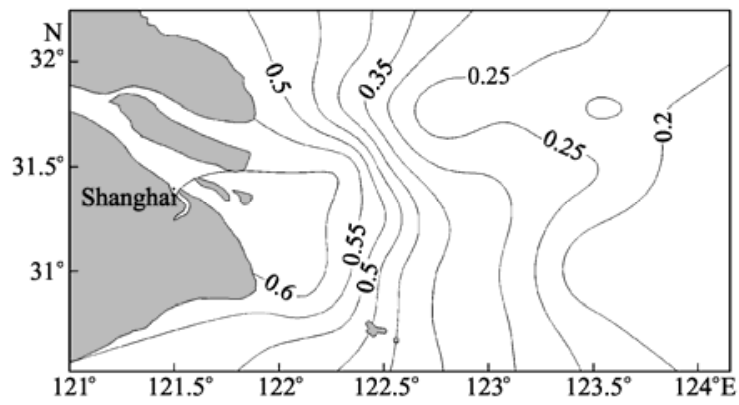

Fig.17 The horizontal distribution of phosphate concentration $(\mu \mathrm{g} / \mathrm{L})$ in July 1986

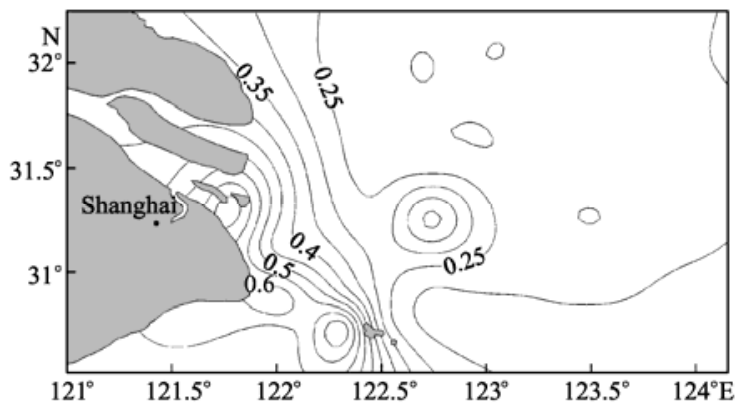

Fig.18 The horizontal distribution of phosphate concentration $(\mu \mathrm{g} / \mathrm{L})$ in August 1986

\subsection{The TWC for the transportation of nutrient $P$ to the estuary}

The TWC is originated from the Taiwan Strait and the Kuroshio, usually extended along the coast of Fujian and Zhejiang Provinces to the north until it meet coastal water current (Weng and Wang, 1984; $\mathrm{Hu}, 1984$; Su and Xu, 1993; Guan, 1986). Many researchers considered that the TWC was composed of two branches: the coastal branch and outside branch. Moreover, no matter what season was, the TWC had two sources ( $\mathrm{Su}$ and $\mathrm{Xu}, 1993$ ).

As a previous study clearly shows, the Taiwan warm current extended along $123^{\circ} 30^{\prime} \mathrm{E}$ from the south to the north. And the front of the surface water reached $31^{\circ} \mathrm{N}$; the deep water extended to the north, 
farther than the surface water, until the north of $31^{\circ} \mathrm{N}$, but not beyond $32^{\circ} \mathrm{N}$ (Weng and Wang, 1984).

The interface between the surface and deep water was generally situated at $50-55 \mathrm{~m}$ near $27^{\circ} \mathrm{N}$. From there northward, with the interface gradually swallowing; for example, the depth was about $25 \mathrm{~m}$ at $30^{\circ} \mathrm{N}$. The interface indicated the deep water rising along the sea bottom slope off Zhejiang Province $\left(28^{\circ}-29^{\circ} \mathrm{N}\right)$, dipping in the same direction to the sea bottom surface. In shore area, the interface rose at 10-15 $\mathrm{m}$ (Weng and Wang, 1984). In the warm water current, the content of $\mathrm{NO}_{3}^{-}-\mathrm{N}$ and $\mathrm{PO}_{4}^{3-}$ -P was lower (Jiang and Wang, 1990). In the south of the East China Sea, a marine water tongue of low oxygen and nutrient from open sea extended from the southeast, and its front reached $31^{\circ} \mathrm{N}$ near the Changjiang estuary and resulted in a large gradient in the concentration from the Changjiang estuary to the open sea off Zhoushan Archipelago (Jiang and Wang, 1990). The data of temperature and salinity from Zhao et al. (1992) indicate that the TWC flowed along a deep channel to northward beyond the Changjiang estuary and reached the marine area at $31^{\circ} 30^{\prime} \mathrm{N}$. Weng et al. (1983) also indicated that the TWC moving along $123^{\circ} \mathrm{E}$ northward could reach $31^{\circ}-32^{\circ} \mathrm{N}$. The related data of euphotic degree and flow survey (Zhao, 1982; 1987) presented that the water body of the TWC extended straightly to the marine area north of $32^{\circ} \mathrm{N}$. After the TWC met the investigation area, it flowed along slope northward, resulting in upwelling in the estuary. Moreover, when the TWC got strengthened, the upwelling in the estuary was enhanced too. In August 1985, the estuary was the center of high nutrient phosphorus at $0.8 \mu \mathrm{mol} / \mathrm{L}$ higher than that in the Changjiang River, showing that the TWC provided the source in the upwelling with nutrient phosphorus taken from the sea bottom. In March 1986, in the estuary parts where upwelling appeared, the phosphate concentration was high at $>0.8$ $\mu \mathrm{mol} / \mathrm{L}$. However, when the TWC weakened, the upwelling in the estuary also weakened and even vanished. In July and August 1986, a weak upwelling was detected, where the phosphate concentration was about $0.6 \mu \mathrm{mol} / \mathrm{L}$. Therefore, in the estuary, the TWC rose along the coast.

In August 1985 in $121^{\circ}$ to $122.25^{\circ} \mathrm{E}$ and $123.5^{\circ}-124^{\circ} \mathrm{E}$, the TWC became an upwelling of high phosphate concentration, shown on the profile of transects $\mathrm{F}$ and $\mathrm{H}$ in August 1985 (Figs.3 and 4) indicating that the sea bottom was disturbed by
TWC with resulting high phosphate concentration there and then shallow places too. At first, the TWC flowed horizontally with very low phosphate concentration at $<0.5 \mu \mathrm{mol} / \mathrm{L}$, and then increased to $0.8 \mu \mathrm{mol} / \mathrm{L}$ boosted by TWC upwelling. The transect profile of $30.5^{\circ} \mathrm{N}$ between $121^{\circ}-122.5^{\circ} \mathrm{E}$ in September 1985 also indicated the TWC upwelling. In November and December 1985, the upwelling centered at $122.25^{\circ} \mathrm{E} / 31^{\circ} \mathrm{N}$. In January 1986 , the upwelling weakened with lower phosphate concentration, and later to March 1986, high phosphate concentration occurred at $122^{\circ} \mathrm{E} / 31^{\circ} \mathrm{N}$. In the months of October 1985, and May, June, July and August in 1986, the TWC did not appear in the Changjiang estuary, while in August, September, November and December 1985, and January and March 1986, it appeared. Therefore, the TWC of low phosphate concentration flowed to the Changjiang estuary from the north to the south and upwelled, resulting in high phosphate concentration from the sea bottom to surface in center of $122^{\circ} \mathrm{E} /$ $31^{\circ} \mathrm{N}$. Moreover, whether the upwelling appeared or not was decided by the intensity of the TWC in a year.

The authors considered that the TWC along the coast arrived at the Changjiang estuary from the south, fresh water of the river in the southern side of the Changjiang estuary, which played a "turning" role in the defection to north of the way of the Changjiang river fresh water.

\subsection{The cyclone-type eddy for the transportation of nutrient $P$ to the estuary}

On continental shelf of the Yellow Sea, there was a cyclone-type eddy in southwest of Jeju Island, Korea. In winter and summer, it rotated counterclockwise, in $124^{\circ} 00^{\prime}-127^{\circ} 00^{\prime} \mathrm{E} / 30^{\circ} 30^{\prime}-30^{\circ} 00^{\prime} \mathrm{N}$ (Hu, 1984) (Fig.19). Above $50 \mathrm{~m}$, the average horizontal divergent degree was positive, called as divergent area, having the strongest horizontal divergent degree at $10 \mathrm{~m}$ which was 1.5-6 times of that in other layers, being the best ambience below the depth of $50 \mathrm{~m}$, the divergent degree was minus, which was called as convergent area.

Every summer in the upper and lower layers of the study areas, cold water mass appeared, whose density was greater than that in east and west sides', and it stayed on slop in a larger scale for a long time. However, near $32^{\circ} \mathrm{N}$, cold upwellings of different intensities occurred, and reached higher place than those in the area of $31^{\circ} \mathrm{N}$ and $33^{\circ} \mathrm{N}$, which occurred in almost every year. The phenomenon indicated 


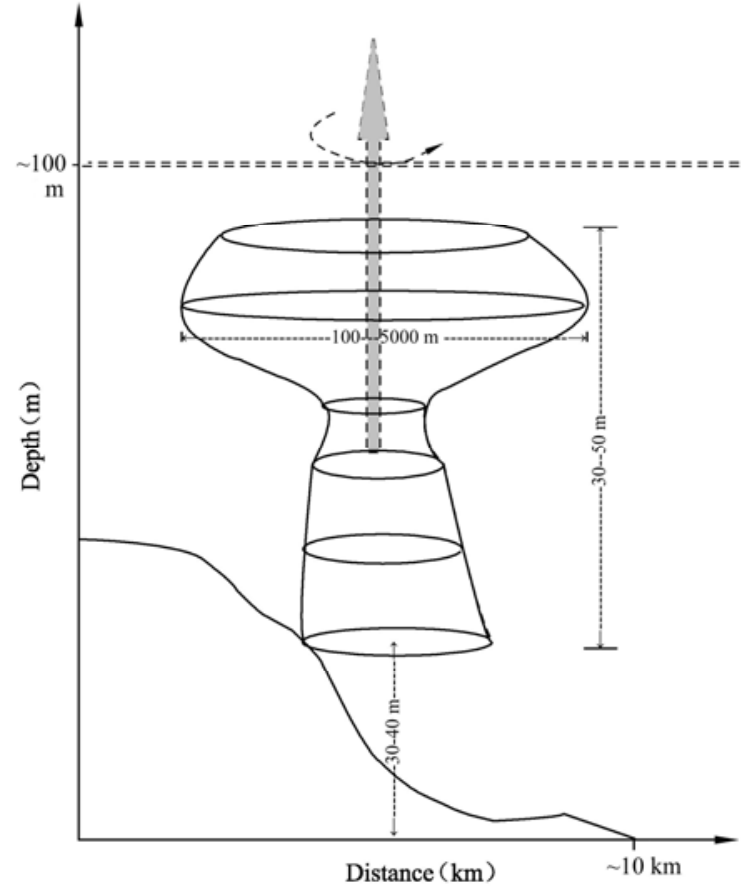

Fig.19 Sketch map showing the cyclone-type eddy occurred In the area $30^{\circ} 00^{\prime}-30^{\circ} 30^{\prime} \mathrm{N} / 124^{\circ} 00^{\prime}-127^{\circ} \mathrm{E}$ (Arbitrary scales)

the summer cyclone-type eddy in this area. The existence of the eddy can be reflected by a round ooze area beneath the eddy, whose size and border agreed with those of the eddy ( $\mathrm{Hu}, 1984)$. The cyclone-type eddy played an important role in disturbing, suspending and transporting substances from the bottom to surface with nutrient-rich cooler waters.

With the values of horizontal divergent degree and vertical flow rate in every layer calculated by $\mathrm{Hu}$ et al. (Hu, 1984), the authors drew a sketch map to depict the eddy's movement (Fig.19). The eddy stayed in situ for a long time and did not shift. If it stayed at the sea bottom, the horizontal rotation resistance could increase, and demanded for more energy to sustain the rotation, forming a upwelling would be very difficult; If it stayed within a water body without touching sea bottom, the friction to its rotation would be small, nutrients at the sea bottom could not reach to the surface by upwelling. However, if the cyclone-type eddy stayed on a slope, it would have smaller friction to rotation and bring up nutrients from sea bottom to surface area by upwelling.

In October 1985, in the area $123.2^{\circ}-124^{\circ} \mathrm{E} / 31.8^{\circ}-$ $32.5^{\circ} \mathrm{N}$, phosphate concentration was high at $>0.8$ $\mu \mathrm{mol} / \mathrm{L}$, which was caused neither by the Changjiang River fresh water, nor by the coastal current. As shown in the profile of the transect $\mathrm{C}$ (Fig.7) through the center of the high concentration

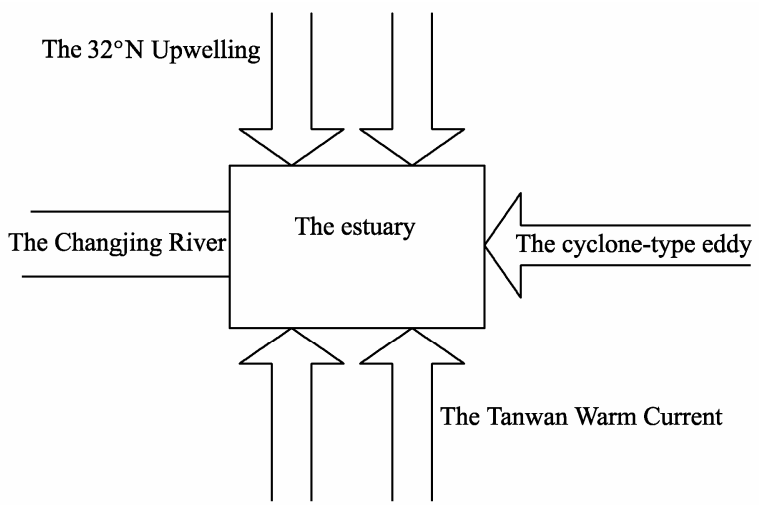

Fig.20 The horizontal distribution of the Changjiang River, the Taiwan Warm Current, the cyclone-type eddy and the $32^{\circ} \mathrm{N}$ Upwelling, supplying the phosphate for the Changjiang estuary

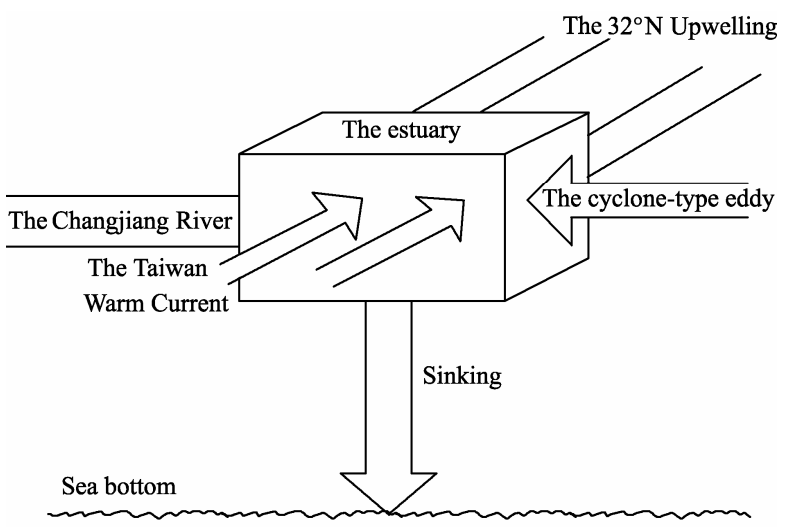

Fig.21 In the Changiiang estuary, the sources and destination of phosphate

area, the high phosphate concentration was found in $0-10 \mathrm{~m}$ east of $124^{\circ} \mathrm{E}$. At the same time, in the area under $10 \mathrm{~m}$ west of $123.2^{\circ} \mathrm{E}$, low phosphate concentration occurred. Therefore, the high phosphate concentration caused most probably, instead of the TWC, by the cyclone-type eddy.

In March 1986, surface waters in $123.5^{\circ}-124^{\circ} \mathrm{E}$ $130.5^{\circ}-32^{\circ} \mathrm{N}$ formed a tongue shaped distribution of high phosphate concentration, indicating the source from the east, or from the cyclone-type eddy clearly, from the marine surface area east of $124^{\circ} \mathrm{E}$.

In May 1986 , in the areas $123.2^{\circ}-124^{\circ} \mathrm{E} / 30^{\circ}-31.4^{\circ} \mathrm{N}$, distributed a high phosphate concentration at over $0.8 \mu \mathrm{mol} / \mathrm{L}$, whose phosphorus source was not from the Changjiang River, nor the coastal Yellow Sea current from the north. The analysis on the transect $G$ profile through the center of the waters and on that of transect $\mathrm{H}$ in the south discovered that the TWC could not develop into a upwelling that could provide abundant phosphate to the waters and caused high phosphate concentration in $0-8 \mathrm{~m}$ deep waters, which was caused by the cyclone-type eddy. 


\subsection{The $32^{\circ} \mathrm{N}$ upwelling for the transportation of nutrient $P$ to the estuary}

In the south of the Yellow Sea, a marine current with high oxygen and high nutrients flowed from northwest to southeast, arrived near $127^{\circ} \mathrm{E} / 31^{\circ} \mathrm{N}$, and converged with the East China Sea and open sea current, forming higher concentration of chemical elements (Jiang and Wang, 1990).

In the area of $124^{\circ}-125^{\circ} \mathrm{E} / 32^{\circ} \mathrm{N}$, there was a circular area of high $\mathrm{O}_{2}, \mathrm{NO}_{3}^{-}-\mathrm{N}$ and $\mathrm{PO}_{4}^{3-}-\mathrm{P}$ values at more than $9.8,13.0$ and $0.7 \mu \mathrm{mol} / \mathrm{L}$ respectively, which probably had relationship with the circular current (Jiang and Wang, 1990).

In January 1986, in the area of $30.9^{\circ}-31.2^{\circ} \mathrm{N} / 121.8^{\circ}-122.2^{\circ} \mathrm{E}$, and in March 1986 in $31.5^{\circ} \mathrm{N} / 124^{\circ} \mathrm{E}$, phosphate concentration was $>$ $0.75 \mu \mathrm{mol} / \mathrm{L}$, which agrees with a former investigation result during January and February 1985 (Jiang and Wang, 1990).

In the north of the estuary, an upwelling was revealed. Surface distribution of phosphate concentration in September 1985 showed that near $32^{\circ} \mathrm{N} / 122.5^{\circ} \mathrm{E}$ was a center of high phosphate concentration at $1.5 \mu \mathrm{mol} / \mathrm{L}$, which was caused by an upwelling, termed as the $32^{\circ} \mathrm{N}$ Upwelling by the authors.

In March 1986, the horizontal surface distribution of the phosphate in the water center of $32^{\circ} \mathrm{N} / 122.5^{\circ} \mathrm{E}$ showed a tongue in historical map with a high phosphate concentration of $0.8 \mu \mathrm{mol} / \mathrm{L}$, which has been discovered that the tongue was caused by the Yellow Sea coastal flow.

\subsection{The relation between phosphate concentration and upwelling intensity}

Strong TWC usually caused higher phosphate concentration as TWC could sweep the sea bottom sediment and would become an upwelling if local bottom geomorphology favored.

In Changjiang estuary, different sources often coexisted that caused high phosphate concentration. In August, September, November and December 1985 and March 1986, there were strong upwellings originated from the TWC, and high phosphate concentration. In January, July and August 1986, the upwellings were weak and disappeared in October 1985 and May to June 1986. Therefore, the upwelling appeared with TWC being strong or weak. All the year round there was the TWC.

The cyclone-type eddy brought up the sea bottom substance to the marine surface by rotating and rising water current. $\mathrm{Hu}$ et al. (Hu, 1984) discovered that the cyclone-type eddy was convergent at the sea bottom, and became strongly divergent in the surface between $0-10 \mathrm{~m}$. Data show that the stronger the cyclone-type eddy was, the higher the nutrient concentration at the surface. Therefore, the magnitude of nutrient concentration in the surface could determine the intensity of the cyclone-type eddy. In October 1985, March and May 1986, the cyclone-type eddy was strong, and the concentration was high at $>0.8 \mu \mathrm{mol} / \mathrm{L}$, while during the rest of the months from August 1985 to August 1986, there was no cyclone-type eddy, and the concentration was low at below $0.6 \mu \mathrm{mol} / \mathrm{L}$.

Similarly, in the case of $32^{\circ} \mathrm{N}$ Upwelling, it brought up nutrient from the sea bottom to the surface. In September 1985 and May 1986, the phosphate concentration in the surface was higher indicating strong upwelling; the high concentration was over $0.8 \mu \mathrm{mol} / \mathrm{L}$, even $2.4 \mu \mathrm{mol} / \mathrm{L}$, while the rest of the months of the investigation, the concentration was $<0.6 \mu \mathrm{mol} / \mathrm{L}$, even $0.3 \mu \mathrm{mol} / \mathrm{L}$, when the upwelling was weak or vanished.

\subsection{The source of phosphate concentration transported to the Changjiang estuary}

The sources of phosphate to the Changjiang estuary included the Changjiang River, the TWC, the cyclone-type eddy and the $32^{\circ} \mathrm{N}$ Upwelling (Fig.20). The Changjiang River provided stable and constant phosphate source causing the concentration between $0.2-0.6 \mu \mathrm{mol} / \mathrm{L}$. The TWC provided high phosphate concentration of $0.8-1.5 \mu \mathrm{mol} / \mathrm{L}$, from August 1985 to August 1986, there was 5 months during which it caused high concentration of about $0.8 \mu \mathrm{mol} / \mathrm{L}, 3 \mathrm{did}$ the low one and at about 0.5 $\mu \mathrm{mol} / \mathrm{L}$. The cyclone-type eddy took effect in three months of a year and the $32^{\circ} \mathrm{N}$ Upwelling did in two months ofa year for generating high phosphate concentration at $>0.8 \mu \mathrm{mol} / \mathrm{L}$. The maximum reached $2.4 \mu \mathrm{mol} / \mathrm{L}$ by the eddy and $1.5 \mu \mathrm{mol} / \mathrm{L}$ by the $32^{\circ} \mathrm{N}$ Upwelling.

The order of these sources in term of supplying phosphate concentration was: The Changiiang River $<$ the TWC $<$ the $32^{\circ} \mathrm{N}$ Upwelling $<$ the cyclone-type eddy. The order in terms of effective time length was: the Changjiang River $>$ the TWC > the cyclone-type eddy $>$ the $32^{\circ} \mathrm{N}$ Upwelling.

\subsection{The phosphate concentration for phytoplank- ton growth in the whole Changjiang estuary}

Changjiang River provided abundant phosphate in concentration of $0.3-0.9 \mu \mathrm{mol} / \mathrm{L}$ into the Changjiang 


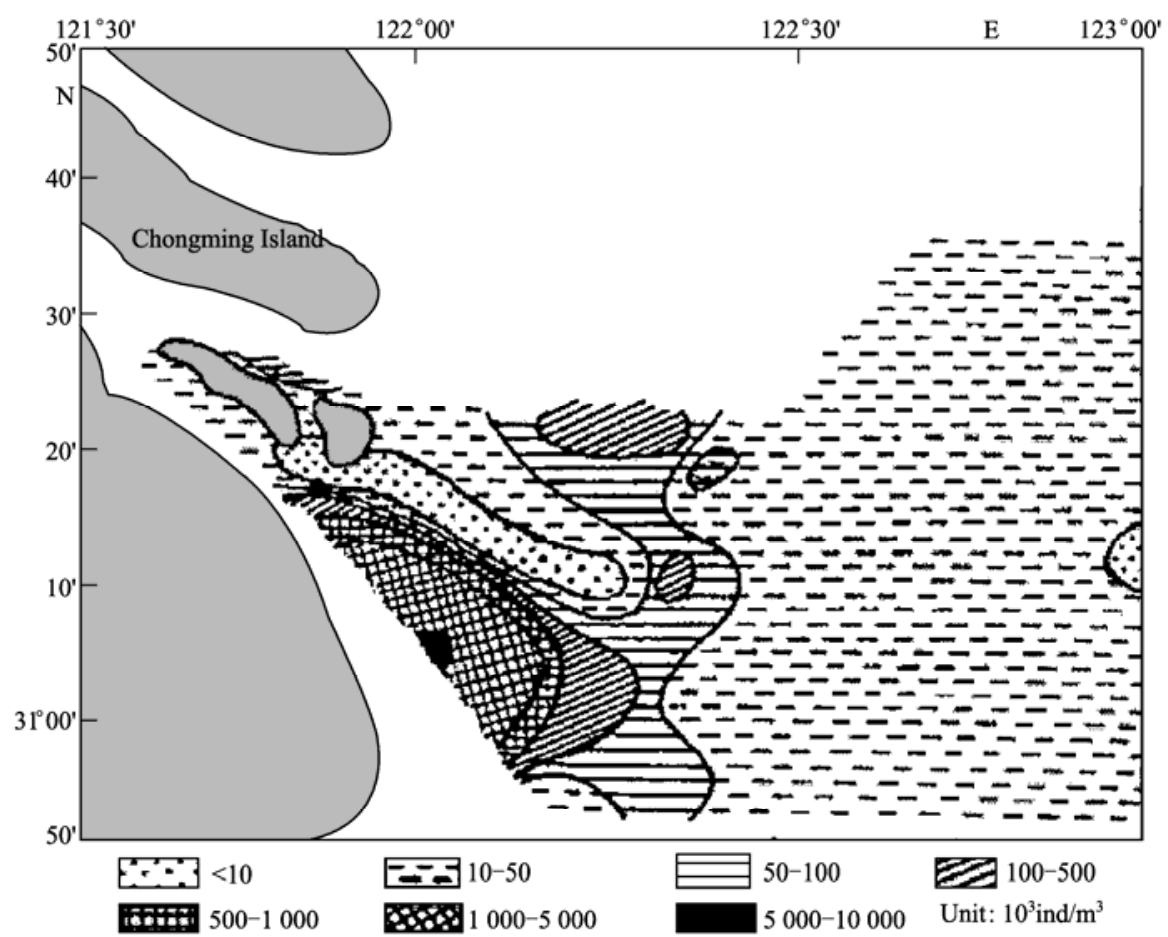

Fig.22 In the Changjiang estuary, the horizontal distribution of phytoplankton biomass (in December 1988) (after Gu et al, 1995)

estuary, of which the phosphate concentration was $0.2-0.6 \mu \mathrm{mol} / \mathrm{L}$ in June, July and August of 1986. In addition, the TWC contributed to the Changjiang estuary with high phosphate concentration $(0.8-1.5 \mu \mathrm{mol} / \mathrm{L})$ during 8 months of a year. For the cyclone-type eddy, it worked for 3 months, and the $32^{\circ} \mathrm{N}$ Upwelling for two months of a year, they generated very high phosphate concentration in the estuary at $1.5-2.4 \mu \mathrm{mol} / \mathrm{L}$. Therefore, supplying phosphate from different directions and time boosted the phosphate concentration up to > $0.2 \mu \mathrm{mol} / \mathrm{L}$. No matter how phytoplankton grew in the whole estuary, blooming or declining, the phosphate concentration satisfied the growth in the whole estuary region (Fig.21).

Where there was no upwelling or weak upwelling in the estuary, phosphate concentration was in a downtrend or constant, when primary production was high, phosphate concentration became low, and vice versa. Where there was a strong upwelling, phosphate concentration was in an uptrend or constant, when primary production was high or low, phosphate concentration became high.

\subsection{The phytoplankton indicating the TWC in the Changjiang estuary}

The horizontal distribution of phosphate shows that the TWC appeared along the coast of the estuary, and centered at $31^{\circ} \mathrm{N} / 122^{\circ} \mathrm{E}$, which is proven by a previous study on phytoplankton ecology in July to August 1988 (high water time) and the in December 1988(low water time) (Gu et al., 1995).

During the high water time, the high value of total amount of phytoplankton appeared in the area $31^{\circ} \mathrm{N} / 122^{\circ} 05^{\prime} \mathrm{E}$ and $31^{\circ} 15^{\prime} \mathrm{N} / 122^{\circ} 15^{\prime} \mathrm{E}$, indicating that phytoplankton came from the upwelling near $31^{\circ} \mathrm{N} / 122^{\circ} \mathrm{E}$

$\mathrm{Gu}$ et al. (1995) also found that predominant species were Rhizosolenia robusta, Coscinodiscus centralis, Rhizosolenia calcaravis and Skeletonema in the estuary. As it has been known that Rhizosolenia robusta is a warm species from open sea and widely distributed in the coastal region of South China from Fujian to Guangxi Provinces (Jin et al., 1965). On the other hand, a study (Gu, 1993) showed that predominant phytoplankton species in the upwelling area were Rhizosolenia robusta and Rhizosolenia calcaravis, taken by the TWC from sub-trpoical to tropical zone to the south in shallow zone of the Changiiang estuary.

Also, Skeletonema, a eurythern and euryhaline species occurred in warm seasons mostly in coastal areas (Kiyozi, 1960). The 
TWC became an upwelling in low water time, and brought up a great amount of Rhizosolenia robusta, Rhizosolenia calcaravis and Skeletonema, becoming the predominant species. Horizontal distribution of phosphate concentration and that of these species had the same pattern (Fig.22), indicating further that the TWC brought predominant algae species with rich phosphate nutrient.

\section{CONCLUSIONS}

Data of 1985-1986 show that phosphate sources in the Changjiang estuary included Changjiang River water to the west, the TWC and its yielding Upwelling to the south, the cyclone-type eddy to the east, and the $32^{\circ} \mathrm{N}$ upwelling to the north (Fig. 21). They supplied phosphate in different concentrations, time, ways and intensities. The order of the scale of supplying phosphate was: the Changjiang River $<$ the TWC $<$ the $32^{\circ} \mathrm{N}$ upwelling $<$ the cyclone-type eddy; and the order of effective time length was: the Changjiang River $>$ the TWC $>$ the cyclone-type eddy $>$ the $32^{\circ} \mathrm{N}$ Upwelling.

Horizontal and vertical distributions of the phosphate concentration showed that near shallow areas at $31^{\circ} \mathrm{N} / 122^{\circ} \mathrm{E}$ in the Changiiang estuary, the TWC with low nutrient concentration became an upwelling through sea bottom and brought the nutrients from the sea bottom to the surface. At the same time, the horizontal distribution of phosphate concentration was consistent with that of warm-water algae species Rhizosolenia robusta, Rhizosolenia calcaravis and Skeletonema that carried out from the south by TWC and dominated in the estuary.

\section{References}

Gu, X. G., 1993. The effect of "engineering of moving the southern water to the north" on phytoplankton. Marine Fishery 1: 8-12. (in Chinese)

Gu, X. G., Q. Yuan and H. T. Sheng, et al., 1995. The ecological study on phytoplankton in maximum turbid zone of changjiang estuary. J. Fish Sci China 2(1): 16-27. (in Chinese)

Guan, B. X., 1986. The outline of current structure and eddy characteristics in East China Sea. Studia Marina Sinica 27: 1-21. (in Chinese)

Hu, D. X., 1984. The study on the cause and its dynamic structure of the upwelling along the Zhenjiang coast. Studia Marina Sinica 21: 101-112. (in Chinese)

Jiang, G. C. and Y. H. Wang, 1990. The distributing characteristics of dissolved oxygen and nutrients in the circumfluence of the East China Sea. Marine Science Bulletin 9(5): 25-31. (in Chinese)

Jin, D. X., J. H. Chen and K. G. Huang, 1965. The Plankton
Diatoms in the Chinese Sea. Shanghai: Shanghai Scientific \& Technical Press. p. 79-94. (in Chinese)

Kiyozi, K., 1960. Phytoplankton. Kosai Sha: Star Publishing House. Translated by Hua R W, Shanghai: Shanghai Scientific \& Technical Press. p. 18-51. (in Chinese)

$\mathrm{Su}$, J. L. and J. P. Xu, 1993. The Kuroshio Study. Qingdao: Qingdao Press. p. 136-139. (in Chinese)

Su, Y. S., 1986. The outline of geography and environment, circulation system and the fishery center in Huanghai Sea and East China Sea. Journal of Shandong Marine College 16(1): 12-26. (in Chinese)

Su, Y. S., Z. X. Yu and F. Q. Li, 1983. the application of clustering analysis in the shallow water mass and the flexible water masses of Huanghai Sea and East China Sea. Oceanologia et Limnologia Sinica 14(1): 1-13. (in Chinese)

Wang, F., D. X. Hu and H. Bai, 2001. The seasonal variation of the seawater distribution and cycle in the west of the East China Sea. Beijing: Ocean Press. p. 66-78. (in Chinese)

Weng, X. C. and C. M. Wang, 1983. The analysis of the variation characteristics of the deep layer in Taiwan warm current. Oceanologia et Limnologia Sinica 14(4): 357-366. (in Chinese)

Weng, X. C. and C. M. Wang, 1984. The preliminary analysis of the summer T-S characteristics and sources in Taiwan warm current. Studia Marina Sinica 21: 113-134. (in Chinese)

Yang, D. F., F. Wang, Z. H. Gao, et al., 2005. An approach to the effect of physicochemical factors on primary production in the Changjiang estuary I. Application of judging methods and rules of nutrient limitation to the Changjiang estuary water area. Advances in Marine Science 23(3): 368-373. (in Chinese)

Yang, D. F., F. Wang, Z. H. Gao, et al., 2006. An approach to the effect of physicochemical factors on primary production in the Changjiang estuary II. Phosphorus is not a limiting factor for phytoplankton growth in the Changiiang estuary. Advances in Marine Science 24(1): 97-107. (in Chinese)

Yang, D. F., Z. H. Gao, F. Wang, et al., 2007. An approach to the effect of physicochemical factors on primary production in the Changjiang estuary III. Makeup of the main water currents supplying phosphorus in the Changjiang estuary. Advances in Marine Science 25(4): 89-112. (in Chinese)

Zhao, B. R., 1982. The effect of the local wind on the coastal shallow current of the Huanghai Sea and East China Sea. Oceanologia et Limnologia Sinica 13(6): 497-490. (in Chinese)

Zhao, B. R., 1987. The preliminary study on the circulation structure of the continental shelf sharp and cold water masses in the west part of the South Huanghai Sea. Oceanologia et Limnologia Sinica 18(3): 217-226. (in Chinese)

Zhao, B. R., K. T. Le and L. B. Zhu, 1992. The upwelling phenomenon and elementary characteristics of temperature and salinity in the Changjiang estuary. Studia Marina Sinica 33: 15-26. (in Chinese) 